DOI: https://doi.org/10.26858/est.v5i3.10873

\title{
The Effectiveness of Blended Learning in Improving Media Literacy on Different Self-Regulated Learning
}

\author{
Muhammad Rais ${ }^{1}$, Ratnawati Fadillah ${ }^{2}$, Andi Alamsyah Rivai ${ }^{3}$ \\ ${ }^{1}$ Agricultural Technology, Universitas Negeri Makassar, Indonesia \\ Email:m.rais@unm.ac.id \\ ${ }^{2}$ Agricultural Technology, Universitas Negeri Makassar, Indonesia \\ Email: ratnamangrove@gmail.com \\ ${ }^{3}$ Agricultural Technology, Universitas Negeri Makassar, Indonesia \\ Email: andi.alamsyah@unm.ac.id
}

(Received: October-2019; Reviewed: November-2019; Accepted: November-2019; Avalaibel Online: December 2019; Published: December-2019)

This is an open access article distributed under the Creative Commons Attribution License CC-BY-NC-4.0 @2019 by author (https://creativecommons.org/licenses/by-nc/4.0/).

\begin{abstract}
The purpose of this study was to examine the effectiveness of learning strategies of blended and self-regulated learning and the effect of the interaction between them on media literacy skills. This study used a quasi-experimental design with a $2 \times 2$ factorial design. The research subjects consisted of 85 people (41 in control groups and 44 in experimental groups). Data were analyzed using two-way ANOVA. The results showed that (1) there were differences in media literacy abilities between groups of students who were taught using blended learning strategies and groups of students who were taught using face to face learning strategies $(\mathrm{F}=26,034 ; \mathrm{p}=$ $0,000)$, (2) there were differences in media literacy abilities between groups of students who have high self-regulated learning and low self-regulated learning, $(F=7,446 ; p=0.008)$, and (3) there was no interaction between learning methods and self-regulated learning (high and low) on literacy skills Student media $(F=0.238 ; p=0.627)$. Descriptive statistical results indicated that the use of blended learning strategies has a better effect with an average score of 37.66 compared to face-to-face learning strategies that have a relatively smaller average score of 34.02 .
\end{abstract}

Keywords: Blended Learning; Self-Regulated Learning; Media Literacy

\section{INTRODUCTION}

A characteristic of the implementation of technology and information in the $21^{\text {st }}$ century is the application of a hybrid learning system or elaboration between learning presented in the classroom and learning outside the classroom connected online. Learning in the era of industry 4.0 is based on the development of industrial technology which is more digitalized. This demands the world of education as the institution that prepared responsive human resources to be anticipative of the demands of the industry 4.0 development.

Designing teaching by utilizing technology has been a must. Through the development and advancement of technology, the use of cyber pedagogics by exploring technology media has significantly contributed to the improvement of the quality of learning. The utilization of the internet as a medium to connect teaching and learning interactions between lecturers and students has been a real condition. Teaching materials, discussions, and academic assignments are presented more dynamically 
and their possibility to be conducted anytime and anywhere in real situations is the portrait of learning in the digital age. Learning in the digital era learning places activities and students as active components to contribute material and create it more dynamically, then it can be accessed openly through available technological facilities. The digital learning era which is referred to as the native digital era, interferes learning as an event that is presented independently, constructively, and innovatively based on the objectives of the learning.

One of the learning methods utilizing the technology of the internet as media which mediates learning is blended learning. Blended Learning means the accumulation of strengths of learning carried out face-to-face or traditionally and virtually (non-face-to-face) (Husamah, 2014). It combines virtual (online) and face-toface (offline) learning delivery strategies that can be through a computer (mobile learning) (Luo, 2014; Kurtanto, Eko, \& Rayandra, 2016; Fan, 2017).

Ultimately, the goal is to improve student learning outcomes, achievements, and independence (Sandi, 2012). This study examined the implementation of blended learning as a method variable that has not been done much in predicting the ability of media literacy. Previous studies about blended learning focused more on cognitive aspects of learning, such as (Kurtanto, Eko, \& Rayandra, 2016) who found that the model is able to significantly increase student understanding. Sutisna Research, 2016) showed that the blended learning model is effective in increasing the learning independence of students in the $\mathrm{C}$ package program at the Center for Community Learning Activities. These empirical facts indicated that blended learning is an option in presenting learning because it is believed possible to improve: 1) pedagogy, access/flexibility, and 3) the effectiveness of cost (Graham, 2005).

In preparing the scenario of blended learning, it requires independent, constructive and creative learning behaviors. In this context, independence commonly acts as a driving factor in online learning. Zimmerman (2004) defines self-regulated learning as the ability to activate self-potential to learn, to make plans, to organize learning, and to monitor and to evaluate the progress of learning that has been delivered. The implementation of blended learning requires good self-regulated learning so that it can be presented effectively.

Studies about self-regulated learning have been enough to provide strong empirical bases that self-regulated learning can assist students to find out the goals of the learning, to direct and to indicate the readiness in determining learning behaviors. Stoegler and Ziegler (2005) found that the intervention of self-regulated learning can reduce the underachievement of children so that they can find their independence learning (Bodrova \& Leung, 2008). Finally, they can get a pleasure learning environment to get an effective learning result (Sungur dan Gungoren, 2009).

Self-regulated learning is a way for someone to organize themselves to synergize with their learning environment, to interact, and to make self-decision to solve various learning problems. The quicker it is, the higher the selfregulated learning they have. On the contrary, the more dependent someone on their environment, and other people in making a decision to study, the higher their dependency on others or their environment so that they can be categorized to have low self-regulated learning.

Considering that the blended learning method is effective to reach the goals of learning that have been previously determined by educators, either teacher to student, or lecturer to university students, it is interesting to study the effect of the implementation of blended learning. Also, learning independence is highly required in the implementation of blended learning, so that the variable of self-regulated learning is also discussed in this study. The purpose is to help students to make themselves independent to utilize media literacy integrated into the blended learning.

Someone who makes himself independent and understands the media is considered to have skills in the use of media, so the high independence and understanding of a person towards media literacy will be directly proportional to the ability to use, to receive and to use media correctly.

Media literacy refers to the abilities of someone to access, process, analyse and use media as instruments to communicate effectively so that they can control them to send and receive messages (Baran \& Dennis, 2010; Lessig, 2011; Tamburaka, 2013). In this context, literacy media means the ability to employ selective, critical, active, and 
constructive thinkings which are expressed through meaningful and ethical acts (Potter, 2014).

Media literacy in this study is the ability of students to use information sources in the form of text, images, graphics, films, videos, and real objects, as a medium that mediates the improvement of learning outcomes.

Learning outcomes are the quantification and qualification of student learning abilities in a particular semester that is achieved from the mastery of media literacy. The concept of media literacy is that students who have high media literacy are those who can sort and choose which media are useful to be applied in learning. On the contrary, low media literacy is indicated by the lack of sensitivity and skills in sorting and choosing media that is useful in praxis learning. This study intended to examine the extent of the influence of blended learning and self-regulated learning strategies in predicting student media literacy, as well as the interaction relationships between learning strategies and self-regulated learning in competing for literacy. It aims to enable students to select, use, and utilize media as an appropriate learning resource in solving learning problems.

\section{METHOD}

This study employed quasi-experimental design that tries to find out the relationship between particular variables (Vockell \& Asher, 1995; Gall, 2003; Salkind, 2006). In this study, all groups received treatments. In this case, the first group used a blended learning method while the second one utilized face to face learning. The design of this experimental study is the version of the version of nonequivalent control group design (Tuckman, 1999) 2X2 factorial. It is shown in Tabel 1 below:

Table 1. Quasi-Experimental Design

\begin{tabular}{cccc}
\hline Pre-Test & \multicolumn{2}{l}{ Treatment } & Post-Test \\
\hline $\mathrm{O}_{1}$ & $\mathrm{X}_{1}$ & $\mathrm{Z}_{1}$ & $\mathrm{O}_{2}$ \\
$\mathrm{O}_{3}$ & $\mathrm{X}_{2}$ & $\mathrm{Z}_{2}$ & $\mathrm{O}_{4}$ \\
\hline
\end{tabular}

Annotation:

$\mathrm{O}_{1,3}=$ the pretest score of medial iteracy skill

$\mathrm{O}_{2,4}=$ the posttest score of medial iteracy skill

$\mathrm{X}_{1} \quad=$ blended learning

$\mathrm{X}_{2} \quad$ = face to face learning

$\mathrm{Z}_{1} \quad$ = high Self-regulated learning

$\mathrm{Z}_{2} \quad$ = high Self-regulated learning

- - - $^{-}=$the whole group
A factorial design is defined as a research structure which confronts two or more independent variables to evaluate their effects independently and interactively on a dependent variable (Sevilla, 1993; Kerlinger, 2000; Gall, 2003). The factorial experimental design indicates that the learning method variable has two dimensions, namely blended and face to face learning as the independent variables. Another independent variable is self-regulated learning (SRL) taken from the Zimmerman model (low SRL and high SRL)). Both SRLs were measured using SRL instruments. The dependent variable is the ability of media literacy.

The subjects of this study were students of the Agricultural Technology Program at Faculty of Engineering, The State University of Makassar in the 5th semester, in the academic year of 2019-2020. The total number of active students in the course of Engineering drawings based on the data from the study program was 44 (in class A) and 41 (in class B). The total number of subjects was 85 . The placement of subjects for the experimental and control classes was based on quasi-experimental characteristics that choose subjects not at random. In other words, subjects have been divided based on existing classes (Salkind, 2006). Based on these characteristics, the subject consisting of two classes that have been formed can be directly taken as an experimental class and a control class. In this case, class A which had 44 people was taken as the experimental class (taught with blended learning) and class B with 41 students were placed as the control class (taught with face to face learning).

Research Procedure. There were two categories of instruments used in this study, including (1) tool to measure the SRL, and (2) check-list to assess the media literacy skills. Data were collected through the following steps: 1) giving SRL test, 2) pre-test, 3) carrying out teaching (experiment) with blended learning method and 4) performing pretest and posttest to students.

The analysis requirements were tested using the data normality and the variance homogeneity tests. The data normality test was carried out with the Kolmogorov-Smirnov technique while the variant homogeneity test was used with the Levene test. The normality and homogeneity tests aimed to meet the parametric assumptions such as 1) the sample must come from a normally distributed 
population, this is better known as the normality assumption concept, 2) the variant values in the sample groups must be homogeneous, or better known as homogeneity assumptions, 3) the data that must be processed must be interval or ratio scale, and 4) the research sample must be taken randomly.

Data were analyzed using parametric statistics, with the two-way ANOVA analysis technique (analysis of variance) (Gall, 2003). 2 x 2 factorial variance analysis was used to test the research hypothesis. Factorial anava or double anava was the parametric statistical technique used to test differences between groups of data derived from two or more independent variables. The null hypothesis testing (H0) was performed at a significance level of $5 \%$ or $=0.05$. To test the research hypothesis, we used SPSS 24.00 for windows.

\section{RESULT AND DISCUSSION}

\section{Result}

\section{Description of Self-regulated learning}

Data of self-regulated learning measurement based on SRL instrument is presented in Table 2 below:

Table 2: Description of SRL

\begin{tabular}{cccc}
\hline & $\begin{array}{c}\text { Blended } \\
\text { learning }\end{array}$ & $\begin{array}{c}\text { Face to } \\
\text { face } \\
\text { learning }\end{array}$ & Total \\
\hline Low-SRL & 12 & 18 & 30 \\
High- & 32 & 23 & 55 \\
SRL & & & \\
\hline Total & $\mathbf{4 4}$ & $\mathbf{4 1}$ & $\mathbf{8 5}$ \\
\hline
\end{tabular}

Data about the average differences in media literacy skills before and after treatment are presented in Table 2 below:

Table 3: The average value of Media Literacy Ability before and after treatment

\begin{tabular}{|c|c|c|c|c|}
\hline $\begin{array}{l}\text { Teaching } \\
\text { Method }\end{array}$ & $\begin{array}{c}\text { Self- } \\
\text { regulat } \\
\text { ed } \\
\text { learnin } \\
\quad g \\
\end{array}$ & $\begin{array}{c}\text { Prete } \\
\text { st } \\
\text { Mea } \\
n \\
(\mathrm{M}) \\
\end{array}$ & $\begin{array}{c}\text { Postte } \\
\text { st } \\
\text { Mean } \\
\text { (M) }\end{array}$ & $\mathbf{N}$ \\
\hline Blended & $\begin{array}{l}\text { Low- } \\
\text { SRL }\end{array}$ & $\begin{array}{l}25 . \\
42\end{array}$ & $\begin{array}{c}37,1 \\
9\end{array}$ & 12 \\
\hline Learning & $\begin{array}{l}\text { High- } \\
\text { SRL }\end{array}$ & $\begin{array}{c}27 . \\
16\end{array}$ & $\begin{array}{c}38,1 \\
8\end{array}$ & 32 \\
\hline
\end{tabular}

\begin{tabular}{ccccc}
\cline { 2 - 5 } & Total & $\mathbf{2 6 . 6 8}$ & $\mathbf{3 7 . 6}$ & $\mathbf{4 4}$ \\
\hline Face to & SRL- & 25. & 32,5 & \multirow{2}{*}{$\begin{array}{c}\text { SR } \\
\text { Face }\end{array}$} \\
Learning & Rendah & 56 & 8 & \\
\cline { 2 - 5 } & SRL- & 24. & 34,6 & \multirow{2}{*}{23} \\
& Tinggi & 65 & 5 & \\
\cline { 2 - 5 } & Total & $\mathbf{2 5 . 0 5}$ & $\mathbf{3 4 . 0}$ & $\mathbf{4 1}$ \\
\hline
\end{tabular}

The average total value of media literacy skills before performing face to face learning with two different self-regulated learning was $\mathrm{M}$ $=25.05$ and after face to face, learning improved to $\mathrm{M}=34.02$. The average total value of media literacy skills before implementing the blended learning in two different self-regulated learning was $\mathrm{M}=26.68$ and after blended learning increased to $\mathrm{M}=37.66$.

In the form of a histogram, the media literacy skills of groups that were taught with the blended learning method and those with the face to face learning method showed differences in their average scores.

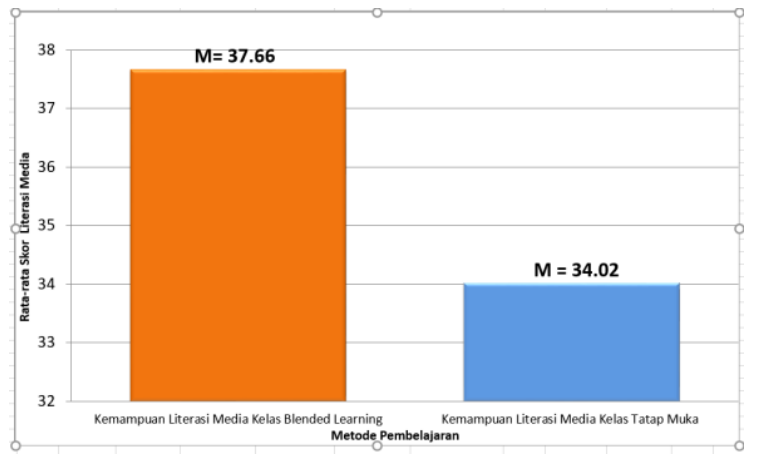

Figure 1. The analysis results of the posttest average score analysis of media literacy skills based on learning methods

It can be seen that students taught with blended learning found a better condition of media literacy learning compared to students learning with face to face methods.

\section{Hypothesis Test}

Testing on hypothesis aimed to explained problems discussed in this study which was formulated as a hypothesis statement. The results of the test performed on the hypothesis are presented in the two path analysis of variance (ANOVA) in Table 4: 
Table 4. The results of statistical tests of media literacy ability based on blended learning and face to face learning methods

\begin{tabular}{lrr|r|r|r}
\hline & $\begin{array}{c}\text { Type III } \\
\text { Sum of } \\
\text { Squares }\end{array}$ & df & Mean Square & \multicolumn{1}{c}{ F } & \multicolumn{1}{c}{ Sig. } \\
\hline Source & $337.783^{\mathrm{a}}$ & 3 & 112.594 & 14.770 & .000 \\
\hline Corrected Model & 94738.903 & 1 & 94738.903 & 12428.015 & .000 \\
Intercept & 198.455 & 1 & 198.455 & 26.034 & .000 \\
Metode_Pembelajaran & 56.758 & 1 & 56.758 & 7.446 & .008 \\
Self_Regulated_Learning & 1.812 & 1 & 1.812 & .238 & .627 \\
Metode_Pembelajaran * & & & & & \\
Self_Regulated_Learning & 617.464 & 81 & 7.623 & & \\
Error & 110540.000 & 85 & & & \\
Total & 955.247 & 84 & & & \\
Corrected Total & & & & & \\
\hline
\end{tabular}

a. $\mathrm{R}$ Squared $=.354$ (Adjusted R Squared $=.330)$

Table 4 above showed that: First, there was a difference in the ability of media literacy between groups of students who were treated with the blended learning method and the ones with the face-to-face learning method with a value of $F=26,034$ which was greater than the value of the $\mathrm{F}$ table $=3.96$ and a probability value of $p=0.000$ which was smaller than alpha 0.05 ( $\mathrm{p}=<0.05$ ), so the null hypothesis (Ho) was rejected. Second, there were differences in media literacy skills between groups of students who had low and high self-regulated learning with a value of $F=7,446$ which was greater than the value of $F$ table $=3.96$ and a probability value of $p=0.008$ which was smaller than alpha 0.05 ( $\mathrm{p}=>0.05$ ), so the null hypothesis (Ho) was rejected. Third, there was no interaction between learning methods and self-regulated learning (low and high) together with the media literacy ability with a value of $F=0.238$ which was smaller than the value of $\mathrm{F}$ table $=3.92$ with a probability value of $p=0.627$ which was greater than alpha $0.05(\mathrm{p}=<0.05)$, so the null hypothesis (Ho) was accepted.

\section{Discussion}

This discussion focuses on the effects of two independent variables of learning method namely blended learning and face to face learning. The dependent variable refers to media literacy skills. In this section the discussion focuses on aspects related to the findings including 1) there were differences in media literacy between students at Department of Agricultural Technology, Faculty of Engineering UNM who were taught with the blended learning method and students who were treated with the face-to-face method, 2) there were differences on media literacy skills between students at Department of Agricultural Technology, Faculty of Engineering UNM who had high self-regulated learning and low selfregulated learning, and 3) there was no interaction between learning methods and selfregulated learning (low and high) on students' media literacy abilities at Department of Agricultural Technology Education, Faculty of Engineering, UNM.

The research findings were compared or matched with theoretical knowledge and the results of earlier studies. Possible implications were then interpreted. The focus of the discussion is the influence of the two independent variables studied, which were the learning methods (blended learning and face-toface learning) and self-regulated learning (high and low) on the dependent variable (media literacy skills).

Based on the description above, there will be three main points to be discussed, including 1) the effect of the learning method on the media literacy skills, 2) the effect of self-regulated learning on the media literacy skills, 3) the effect of the interaction of the learning method and the self-regulated learning on the media literacy skills.

\section{The Effect of Learning Method on Media Literacy Skills}

Hypothesis testing showed that there were differences in the media literacy skills between groups of students who were treated with the blended learning method and groups of students 
taught with face-to-face learning methods in the Agricultural Technology Education program. The mean score of media literacy skills of students who used the blended learning method was higher than the mean score of media literacy skills of students who used the face-toface learning method.

The difference found in mean scores of students' media literacy skills in this research indicated that the implementation of blended learning methods more positively influences on media literacy skills compared to the use of face-to-face learning methods.

This study indicates that the blended learning method has significantly improved the ability of students' media literacy. Through blended learning, students in groups were more curious and possibly invent new concepts about media literacy, more eager to use the media, and better in choosing and sorting out useful media as learning resources. It was because through the blended learning, students were directly connected to the internet that allows them to explore the media literacy in a more dynamic learning environment and time, so that those activities could provide an interesting and more pleasant atmosphere, which finally created a better collaboration and aroused learning motivation for mutual discussion by utilizing existing internet media (Vaughan, 2014; Saritepeci and Cakir, 2015; Akgunduz and Akinoglu, 2016).

As a learning method, blended learning aims to accommodate the nature and characteristics of learners in the 21 st century. This era is marked by the rapid progress and remarkable diversity of learning systems design based on technology literacy. This underlies why students seem to more enjoy the learning atmosphere when treated with blended learning strategies. The nuances of learning are presented independently to support students in solving problems with high cognitive flexibility (Orendain \& Wood, 2012; Yurdakul, 2014; Leana, 2016). Students construct their thinking to look for information from reading sources on the internet which can be in the form of text, graphics, pictures, charts, and learning videos as references in discussions. The use of information resources provided in blended learning supports media literacy skills.

Characteristics of good media literacy include how high students' interest and how often they extract information from technologybased learning media, such as the internet. The ability and maturity to choose the material based on needs in blended learning shows the level of student maturity in media literacy. This confirms that blended learning has been quite effective in leading learning independence on students to train themselves to use constructive media in facilitating learning goals. Those abilities include the ability to access, understand, and create communication in various learning contexts (Oesterman, 2012)

\section{Effects of Self-Regulated Learning on Media Literacy Skills}

Various studies showed that selfregulated learning has been quite contributive in encouraging the acquisition of effective learning results. Self-regulated learning is empirically able to regulate students in directing their learning orientation. In this study, self-regulated learning was measured using the inventory of self-regulation in learning. Students with low self-regulated learning do not have a positive contribution in encouraging their 'media literacy skills, while those with high self-regulated learning have sufficiently influenced the ability of students' media literacy.

This study found that self-regulated learning, both high and low showed a significant influence in accommodating the ability of students to use their creative thinkings to choose and sort media that is suitable for reading. The influence of self-regulated learning on students' media literacy skills shows that the theory of self-regulated learning supports Bandura's (1986) learning theory that self-regulated learning has three main elements including personal, environmental, and behavior. Personal indicates the students' personality as selfregulated learners, the environment as a place of learning for students to implement their learning praxis, and their behavior shows the observed and implemented characters in their personality and learning environment.

The cycle of self-regulated learning indicates an operational and reflective environment for students to consistently make effective learning plans, carry out concrete actions, and evaluate learning outcomes. That cycle is reflected through the activities in blended learning, as the construction of student learning requires independent and structured activities. It is regarded to be independent because activities in blended learning are presented in cyberspace that is not directly 
observed by lecturers. In this case, we need trust, confidence, and independence. These three values need to be strengthened to students so that they can truly achieve their learning goals independently. According to Zimmerman (1989), three aspects that influence each other in improving the effectiveness of a learning are 1) influence from inner self, the belief that someone is capable to do and the knowledge they have to progress and develop, 2) the influence of behavior indicated from the ability to observe, assess, and perform, 3) the influence of the environment, which gives chance for students to interact and socialize in diverse communities with interactive and dynamic communication patterns. These three things become capitals in practicing activities in blended learning. In this research, these three components have been applied effectively, both at the beginning of learning when students studied online for the first time, students were given an explanation so that they could truly be independent and were able to occupy the learning environment effectively and efficiently.

The students' ability to choose and sort out suitable media for their needs shows a positive trend and the fact that media literacy was good enough to regulate themselves, and that self-regulation is good learning has a positive effect on students in conducting online learning practices. It can be seen when students were connected with cyberspace, that they focused more on searching material and eliminating activities that were not related to the substance of learning in blended learning.

\section{Effects of interaction between learning methods and self-regulated learning on student media literacy}

Interaction occurring in the learning activities shows the relationship between several predictor variables with predicted variables. The effect of interaction in a study is the joint influence of two or more of the independent variables on the dependent variable (Kerlinger, 2000; Ghozali, 2009).

The learning methods which were used and self-regulated learning were not significant in improving students' media literacy abilities. Statistical analysis showed that the two variables were not contributive in producing students' media literacy abilities. In other words, learning methods and self-regulated learning are not mutually interactive encouraging student success in choosing, assessing and sorting out which media were suitable and in accordance with their learning needs, and separately are not influenced by learning strategies and selfregulated learning. And vice versa, selfregulated learning is more effective to support students' literacy skills, and learning methods are more contributive to emerge students' media literacy skills.

Considering that the two variables were ineffective in boosting students' media literacy abilities, it is better to including only one variable in learning which is more effective in generating media literacy abilities.

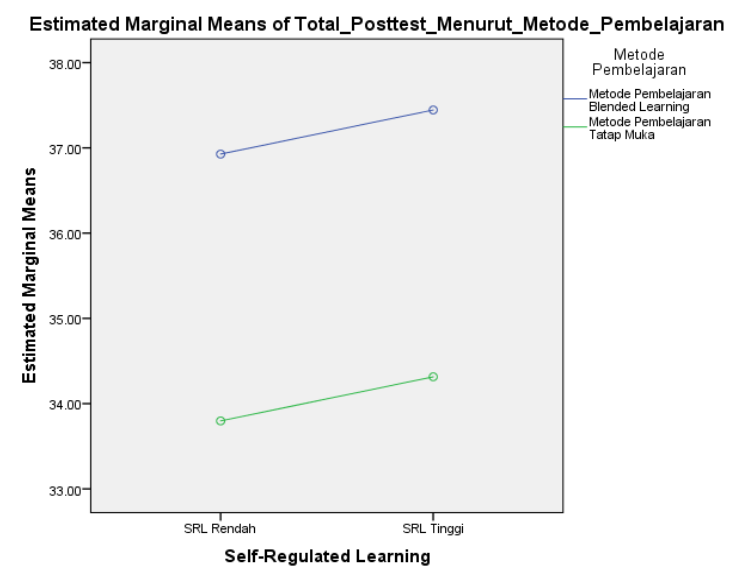

Figure 2. The plot of Posttest mean scores that show there is an interaction between learning methods and self-regulated learning

Figure 2 clearly indicates that there was no mutual effect between the learning methods (blended learning and face to face) and selfregulated learning (high and low). The figure above shows the lines describing the rate of selfregulated learning in blended learning methods situated above the levels of self-regulated learning in face-to-face learning. The two lines show do not touch each other or form an intersection in the middle or at the ends that could indicate the existence of an interaction, but the two graphs above still show similar but not significant interaction patterns.

Figure 2 also shows that the implementation of both blended learning and face-to-face learning methods made students with high self-regulated learning have higher media literacy abilities than students with low self-regulated learning. Also, students with auditory learning styles had higher technical 
drawing ability than students with visual learning styles.

\section{CONCLUSIONS AND SUGGESTION}

Based on the research findings discussed above, it can be concluded that the blended learning method influences the media literacy skills. The utilization of the blended learning method can encourage students to learn more independently and to train themselves to use constructive media in facilitating learning objectives. Students are more able to access, understand and communicate effectively in various learning contexts through the application of media literacy.

The students' independence in organizing themselves to select and utilize media literacy based on the needs shows good self-regulated learning. Thus students' behavior, character, attitude, motivation, and metacognition can always be integrated or reflected in themselves.

\section{REFERENCES}

Akgunduz Devrim, Devrim \& Akinoglu, Orhan. (2016). The Effect of Blended Learning and Social Media-Supported Learning on the Students'Attitude and Self-Directed Learning Skills in Science Education. TOJET: The Turkish Online Journal of Educational Technology. 15 (2).106-115. 1

Bandura, A. (1986). Social learning Theori. Englewoods Cliffs, NJ: Prentice Hals

Baran, Stanley J dan Davis, Dennis K. (2010), Teori Komunikasi Massa. Jakarta : Salemba Humanika

Bodrova, E. \& Leong, D.J. (2008). Developing self-regulation in kindergaten. Beyond the Journal. NAECSinState Departement of Education.

Fan, M. S., Wu, F. T., \& Wang, Y. (2017). Research on Blended Learning Model Based on Electronic Schoolbag. China Educational Technology, No. 10, 109117

Gall, M.D., Gall, J.P., \& Borg, W. R. (2003). Educational research: An Introduction. Seventh Edition. Boston: Pearson Education,Inc.
Ghozali, I. (2009). Aplikasi Analisis Multivariate dengan Program SPSS. Semarang: Badan Penerbit Universitas Diponegoro.

Graham, C. (2005). Blended learning systems: Definition, current trends, and future directions. In C. Bonk and C. Graham (Eds.). Handbook of Blended Learning:

Husamah. (2014). Pembelajaran Bauran (Blended Learning). Jakarta: Prestasi Pustaka.

Kerlinger, F. N. (2000). Asas-Asas Penelitian Behavioral. Terjemahan oleh Landung R. Simatupang. 1990. Yogyakarta: Gajah Mada University Press.

Kurtanto, Eko, \& Rayandra. (2016). Pengembangan Model Pembelajaran Blended Learning Pada Aspek Learning Design Dengan Platform Media Sosial Online Sebagai Pendukung Perkuliahan Mahasiswa. pp. 1-26.

Leana, Marilena Z,. (2016). The relationships between self-regulated learning skills, causal attributions and academic success of trainee teachers preparing to teach gifted students. Educational Research and Reviews.11 (13). 12171227.DOI: 10.5897/ERR2016.2818.

Lessig, Lawrence. (2011). Budaya Bebas: Bagaimana Media Besar Memakai Teknologi dan Hukum untuk Membatasi Budaya dan Mengontrol Kreativitas. KUNCI Cultural Studies Center: Jogjakarta

Luo, J. T., Sun, M., \& Gu, X. Q. (2014). The Innovation Research of MOOC from the Perspective of Blended Learning: Case Study of SPOC. Modern Educational Technology, 24, 18-25.

Oesterman, M. D. (2012). Digital literacy: Definition, theoretical framework, and competencies. In M. S. Plakhotnik, S. M. Nielsen, \& D. M. Pane (Eds.), Proceedings of the 11th Annual College of Education \& GSN Research Conference (pp. 135-141). Miami: Florida International University. Retrieved from 
Orendain, A. O. \& Wood, S. (2012). An account of cognitive flexibility and inflexibility for a complex dynamic task. [Online] Available: http://actr.psy.cmu.edu/papers/1035/paper0009. pdf (October 10, 2019)

Potter, W. (2014). Media literacy (Seventh ed.). Washington DC: SAGE

Salkind, J. Neil. 2006. Exploring research: Sixth Edition. New Jersey: Prentice Hall.

Sandi, G. (2012). Pengaruh Blended Learning terhadap Hasil Belajar Kimia Ditinjau Dari Kemandirian Siswa. Jurnal Pendidikan dan Pengajaran, 241-251.

Saritepeci, Mustafa \& Cakir, Hasan. (2015). The Effect of Blended Learning Environments on Student Motivation and Student Engagement: A Study on Social Studies Course. Education and Science. 40 (177). 203-216.

Stoegler, H. \& Ziegler, A. (2005). Evaluation of an elementary clasroom self-regulated learning program for gifted mathematics underachievers. International Educational Journal, 6(2), 261-271. ISSN 14431475@2005Shannon Reseach Press.

Sungur, S \& Gungoren. (2009). Effect of problem-based learning and traditional intruction on self-regulated learning. The journal of Educational Reseach, 99, 307-317.
Sutisna, A. (2016). Pengembangan Model Pembelajaran Blended Learning pada Pendidikan Kesetaraan Program Paket C dalam Meningkatkan Kemandirian Belajar. Jurnal Teknologi Pendidikan, 156-168.

Tamburaka, A. (2013). Literasi Media: Cerdas Bermedia Khalayak Media Massa, Jakarta: Rajawali Pers.

Tuckman, W. B. (1999). Conducting Educational Research: Second Edition. USA: Harcourt Brace Jovanovich, Publisher.

Vaughan, Norman. (2014). Student Engagement and Blended Learning: Making the Assessment Connection. Education Science. 4, 247-264; doi:10.3390/educsci404024.

Vockell, Edward L. \& Asher, J W. (1995). Research Educational. New Jersey Ohio: Merrill an Imprint of Prentice Hall.

Yurdakul, Bunyamin., (2014). The Effect of Blended Learning on Students' Achievement, Perceived Cognitive Flexibility Levels and Self-Regulated Learning Skills. Journal of Education and Practice. (5) 22. 176-196.

Zimmerman, B.J. (1989). A Social Cognitive View of Self-Regulated

Zimmerman,B.J. (2004). A social cognitive view of self-regulated academic learning.Journal of Educational Psychology,4, (2), 22-63. 